\title{
Ligeiras Notas sobre a imagem (como se ela fosse uma coisa ou alguém)
}

Luisa Günther

O que não sei fazer desconto nas palavras

Entesouro frases.

Por exemplo Imagens são palavras que nos faltaram

Poesia é a ocupação da palavra pela Imagem

Poesia é a ocupação da Imagem pelo Ser

Manoel de Barros

\section{Era uma vez}

uma imagem.

Impecável.

Inquestionável.

Verosímil.

Forjada em sua postura de corroborar a apresentação de qualquer algo.

Não entrava no mérito.

Observadora atenta, a imagem aparentava, sempre, certo recato perante as circunstâncias.

Afinal, só importavam as aparências. 
Sua principal desenvoltura era não piorar as situações.

Acima de qualquer desfeita,

Militante das boas impressões, jamais opinava sem antes destilar a sensibilidade (ou) sem antes analisar todas as referências e princípios de realidade. precisava manter sua integridade diante deturpações e interesses tão próprios dos menos afortunados e torpes.

Sua principal meta: austeridade, sem juízo de valor. Longe de ser enfadonha, a imagem cuidava de suas relações com um afinco invejável a qualquer pária.

Sempre na moda. Sempre convidada.

Invejada.

Desejada.

Descolada.

Era sempre a primeira a tecer comentários inteligentes sobre as notícias da semana.

Mesmo as polêmicas (mas só aquelas que já haviam reverberado o zunzunzun necessário)

Diante tanto empenho, tanto artificialismo em parecer tão natural, aconteceu o insuspeito: em meio a um deselegante transtorno causado por outros, preferiu não tomar partido,

nem emitir opinião.

Arf! Preguiça desta mania ignóbil que os carentes (ou frustrados, ou pior: perseguidos e vitimados)

tem de chamar para si a atenção. 
Preferiu ignorar tudo

por medo das eventuais rugas

que poderiam brotar em seu semblante tão íntegro.

\section{Como era de sua praxe,} a imagem permaneceu reservada em seu nicho de dignidade.

Só que, desta vez,

a tão enfadonha alteridade responsável por aquele transtorno, era ela.

\section{Como?!}

Também.

Após tanto esforço em ser quase-blasé, sua reputação estava em risco. 0 quê fazer?

0 susto a fez consultar normas e resoluções; livros de etiqueta, manuais, horóscopo e tarô.

Até entender a dimensão do que estava acontecendo, já era tarde demais.

Tornara-se cúmplice-por-conivência. Seu conveniente distanciamento, era covardia. Seu tão bem elaborado parecer técnico era anacrônico (quase cômico).

\section{Todas as injúrias já haviam sido proferidas até o momento.}

A pior delas foi o silêncio. Atônita, a imagem percebeu que deveria ter corrido o risco de ser ridícula. Poderia até ter se dado o luxo de estar errada. Afinal, poderia sempre, pedir desculpas.

Agora, tudo estava tão exageradamente escancarado... que teve uma síncope. 0 tempo, irreversível, impediu que a imagem desfizesse sua desfeita em não ser espontânea .

Com isto, a imagem descobriu que, no drama da vida cotidiana, todos fazem parte. Ninguém tem o direito de ser mero espectador do vexatório, do injusto, do desdém.

Destituída de seu estatuto, a imagem passou a ser coisa.

Qualquer.

Quase-nada.

Tanto-faz. 